$5-21-2020$

\title{
Search Engines and Global Takedown Orders: Google v Equustek and the Future of Free Speech Online
}

Robert Diab

Thomson Rivers University, rdiab@tru.ca

Follow this and additional works at: https://digitalcommons.osgoode.yorku.ca/ohlj

Part of the Internet Law Commons

Article

\section{(c) (1) (9)}

This work is licensed under a Creative Commons Attribution-Noncommercial-No Derivative Works 4.0 License.

\section{Citation Information}

Diab, Robert. "Search Engines and Global Takedown Orders: Google v Equustek and the Future of Free Speech Online." Osgoode Hall Law Journal 56.2 (2019) : 231-270.

https://digitalcommons.osgoode.yorku.ca/ohlj/vol56/iss2/1

This Article is brought to you for free and open access by the Journals at Osgoode Digital Commons. It has been accepted for inclusion in Osgoode Hall Law Journal by an authorized editor of Osgoode Digital Commons. 


\title{
Search Engines and Global Takedown Orders: Google v Equustek and the Future of Free Speech Online
}

\begin{abstract}
The Supreme Court's decision in Google v Equustek (2017) to uphold a global content takedown order remains controversial and consequential to wider debates about governing the internet. This commentary examines the Court's underlying assumption - a common view in takedown jurisprudence - that where a portal directs a critical mass of users to a harmful site, it facilitates harm and no longer engages in valuable speech. This ran contrary to the Court's more considered view of links in Crookes v Newton (2011) as a form of mere reference and valuable per se for enabling the internet as a public forum. This commentary argues the Court should have applied its theory from Crookes to search engine links as no different in principle from others, while conceding that, at scale, links that merely refer can facilitate harm. Drawing on the Copyright Act and the Manila Principles on Intermediary Liability, the author proposes a test for takedown orders that strikes a better balance between free speech and private interests.
\end{abstract}

\section{Keywords}

Injunctions; Internet--Law and legislation

\section{Creative Commons License}

(c) (i) $\Theta$

This work is licensed under a Creative Commons Attribution-Noncommercial-No Derivative Works 4.0 License. 


\title{
Search Engines and Global Takedown Orders: Google $v$ Equustek and the Future of Free Speech Online
}

\author{
ROBERT DIAB*
}

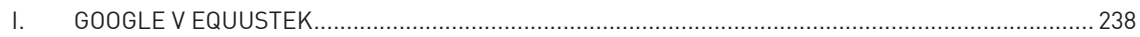

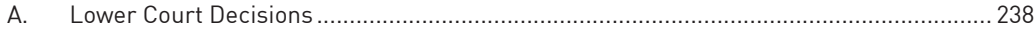

B. Supreme Court Decision ................................................................................... 249

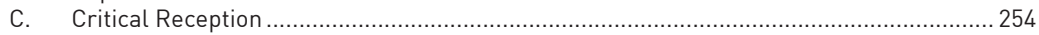

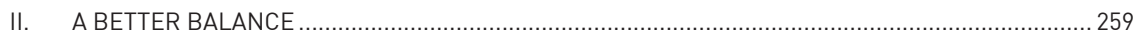

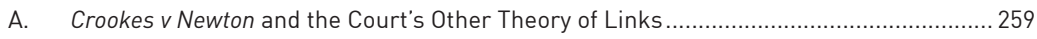

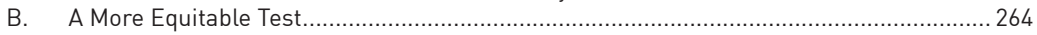

The Supreme Court's decision in Google v Equustek (2017) to uphold a global content takedown order remains controversial and consequential to wider debates about governing the internet. This commentary examines the Court's underlying assumption - a common view in takedown jurisprudence - that where a portal directs a critical mass of users to a harmful site, it facilitates harm and no longer engages in valuable speech. This ran contrary to the Court's more considered view of links in Crookes v Newton (2011) as a form of mere reference and valuable per se for enabling the internet as a public forum. This commentary argues the Court should have applied its theory from Crookes to search engine links as no different in principle from others, while conceding that, at scale, links that merely refer can facilitate harm. Drawing on the Copyright Act and the Manila Principles on Intermediary Liability, the author proposes a test for takedown orders that strikes a better balance between free speech and private interests.

Associate Professor in the Faculty of Law at Thomson Rivers University, rdiab@tru.ca. 
Google $v$ Equustek $^{1}$ has garnered worldwide attention as a case at the forefront of a trend, on the part of national courts and regulators, to assert broad jurisdiction in issuing content takedown orders against search engines and other online intermediaries. ${ }^{2}$ Although international law has long recognized that free speech may be justifiably limited to prevent crime or defamation, ${ }^{3}$ how best to apply this principle to search engines and other intermediaries has been the subject of increasing litigation and debate. ${ }^{4}$ One area of concern involves a recognition, primarily in Europe, of a "right to be forgotten," which has been held to justify

1. Google Inc v Equustek Solutions Inc, 2017 SCC 34 [Equustek].

2. See the survey of cases set out in Alicia Solow-Niederman et al, "Here, There, or Everywhere? Assessing the Geographic Scope of Content Takedown Orders" (2017) Harvard Law School \& Berkman Klein Center for Internet \& Society Working Paper, online: <clinic. cyber.harvard.edu/files/2017/03/Here-There-or-Everywhere-2017-03-27.pdf> [perma. cc/3WC9-NNGZ]. For notable decisions, see Google Spain SL v Agencia Española de Protección de Datos (AEPD), C-131/12, [2014] ECR I-00000 [Google Spain]; Commission Nationale de l'Informatique et des Libertés, 21 May 2015, Décision n ${ }^{\circ} 2015-047$ du 21 mai 2015 [2015] [CNIL]; Trib gr inst Paris, 6 November 2013, Max Mosley c Google Inc et Google France [2013] RG 11/07970 [Mosley France]. In Google Spain, the Court of Justice of the European Union interpreted a European Council directive on personal data to order Google to remove links to content relating to the claimant's past financial activities-though the decision is unclear as to the territorial scope of the order. In CNIL, the French Data Protection Authority ordered Google to globally delist links to sites in cases involving European data protection law; initially appealed to France's Conseil d'État but now referred to the European Court of Justice and pending. In Mosley France, the Tribunal de Grand Instance de Paris ordered a global delisting of content on Google Images. See also EC, Regulation (EU) 2016/679 of the European Parliament and of the Council of 27 April 2016 on the protection of natural persons with regard to the processing of personal data and on the free movement of such data, and repealing Directive 95/46/EC (General Data Protection Regulation), [2016] OJ, L 119/1. Powers of European courts and regulators to issue extra-territorial content takedown orders against online intermediaries will expand as the 2016 General Data Protection Regulation (GDPR) takes effect in 2018. For an overview of the GDPR in this context, see Daphne Keller, “The Right Tools: Europe's Intermediary Liability Laws and the 2016 General Data Protection Regulation" (2018) 33 BTLJ 297.

3. See Convention for the Protection of Human Rights and Fundamental Freedoms, 4 November 1950, 213 UNTS 221 art 10 (entered into force 3 September 1953). Article 10 of the European Convention on Human Rights (ECHR) asserts the right to freedom of expression "subject to such formalities and conditions ... as are prescribed by law and are necessary in a democratic society ... [including] the prevention of disorder or crime ... [or] the protection of the reputation or rights of others." See also International Covenant on Civil and Political Rights, 19 December 1966, 999 UNTS 171 art 19 (entered into force 23 March 1976, accession by Canada 19 May 1976). Article 19 contains similar language to Article 10 of the ECHR. See also Agnes Callamard, "The Control of 'Invasive' Ideas in a Digital Age" (2017) 84 Soc Research 119 (examining recent trends in the regulation of speech online in light of a broader history of the right to free expression in international law).

4. Callamard, supra note 3. See also the survey of cases set out in Solow-Niederman et al, supra note 2 . 
orders compelling intermediaries to remove content to prevent reputational harm. ${ }^{5}$ Another area of concern is intellectual property law, in which courts and legislatures throughout the world have grappled with the responsibilities of search engines and other intermediaries in preventing piracy. ${ }^{6}$ In both contexts, a view has emerged to the effect that where a portal's links direct a critical mass of users to a site, they facilitate the harm at issue and no longer engage in protected speech (what can be called the "critical mass theory of links"). Taking this

5. See e.g. NT1 \& NT2 v Google LLC, [2018] EWHC 799 (QB) at para 223 (ordering Google to delist links to information about an applicant's past criminal conviction that was held to be "out of date, irrelevant and of no sufficient legitimate interest to users of Google Search to justify its continued availability"). See also Google Spain, supra note 2; Mosley France, supra note 2. For a recent overview of law and scholarship on the right to be forgotten, see Jennifer Daskal, "Borders and Bits" (2018) 71 Vand L Rev 179 at 210-18. On the application of the concept in the Canadian context, see Andrea Slaine, "Search Engines and the Right to be Forgotten: Squaring the Remedy with Canadian Values on Personal Information Flow" (2018) 55 Osgoode Hall LJ 349.

6. Cartier International AGv British Sky Broadcasting Limited, [2016] EWCA Civ 658 [Cartier $\mathrm{CA}$ ] (Court of Appeal for England and Wales upholding an order against five internet service providers to block access to websites selling counterfeit copies of the plaintiffs' goods); CA Paris, 15 March 2016, Association des Producteurs de Cinéma (APC) v Orange SA (2016) Commercial Court No 2 of Barcelona, No 14/01359 [APC $v$ Orange] (ISPs ordered to block and search engines to delist movie streaming sites); Disney Entertainment Inc v Telenor Norge AS, Case No 16-072899TVI-OTIR/08, Oslo District Court, 22 June 2016 [Disney v Telenor] (ISP ordered to block a streaming site); Asociacion de Gestion de Derechos Intelectuales v Jazz Telecom, Judgment No 219/16, 2nd Commercial Court of Barcelona, 25 July 2016. See also Canada's Copyright Modernization Act, SC 2012, c 20 [CMA] (adding section 41.27 to the Copyright Act, RSC 1985, c C-42, which allows for search engine de-listing orders in copyright infringement cases [discussed further in Part II of this paper]); the Stop Online Piracy Act, HR 3261 (a bill of the US House of Representatives in 2011 containing provisions for search engine delisting orders in copyright infringement cases-but not passed); and the Digital Economy Act 2010 (UK), c 4 (a UK bill containing sections 16 and 17 allowing for removal orders against search engines in copyright infringement cases, though the provisions were later repealed).

7. See e.g. Disney v Telenor, supra at note 6. The court states that: "[a]s neutral intermediaries, they have the best opportunity to stop infringements by blocking their customers' access to websites where infringements take place on a large scale"; APC $v$ Orange, supra at note 6 (the court ordering search engines to delist streaming sites, declining to accept that search engines play a neutral role). The critical mass theory of linking is also implied in a number of US district court decisions in intellectual property infringement cases, in which courts impose delisting orders against non-party search engines or ISPs as incidental features of an injunction primarily aimed at the infringing defendant. See e.g. Hermès International v John Doe et al, 12 Civ 1623 (SDNY 2012) [Hermès]; Chanel Inc v Does, 11-Cv-01508-KJD-PAL (D Nev, November 14, 2011) [Chanel]; ABS-CBN Corporation v Ashby, 3:14-cv-01275-HU (Dist Or 2014); Richemont International SA v Chen, 1:12-cv-06689 (SDNY 2013), ABS-CBN Corporation v Cinesilip.net, 2017 WL 1628900 (SD Fla 2017) [ABS-CBN]; and American Chemical Society v John Does 1-99, 1:17-cv-726-LMB-JFA (ED Vir 2017) 
approach, courts and lawmakers have crafted rules for content removal against intermediaries that have broad implications for freedom of expression online.

The Supreme Court of Canada's 2017 decision in Google v Equustek exemplifies this approach. ${ }^{8}$ As the first decision from an apex court in which a search engine was directly enjoined—globally—from including links to a site alleged to be hosting pirated content, ${ }^{9}$ it garnered considerable attention and criticism worldwide, ${ }^{10}$ and has begun to serve as a precedent. ${ }^{11}$ However, it has thus far not received much scholarly attention and, given its potential import

[American Chemical]. Among the reputational harm cases, the critical mass theory is also discernible. See e.g. Google Spain, supra note 2 at paras 35, 80, 81 (on the "significant" effect of search engines on personal privacy and data compared to individual sites, and the need to protect privacy generally overriding the public interest in access to information). Distinguished from the reasoning in these cases are those in which a search engine's auto-complete or snippet-view functions are held to repeat a defamation, making the search index a secondary publisher. See e.g. Google Inc v Duffy [2017] SASC 130; Google Inc v Trkulja [2016] VSCA 333.

8. Equustek, supra note 1.

9. See also Google Spain, supra note 2. This case is a key precedent, ordering Google to remove links in a reputational harm case. As noted, the decision did not make the territorial scope of the order clear and the matter is pending before the CJEU.

10. Hamza Shaban, "How a Supreme Court case in Canada could force Google to censor speech worldwide" (29 June 2017), online: <www.washingtonpost.com/news/the-switch/ wp/2017/06/29/how-a-supreme-court-case-in-canada-could-force-google-to-censor-speechworldwide/?noredirect=on\&utm_term=.42737d9cf9ac $;$; Guardian, "Google can be forced to pull results globally, Canada supreme court rules" (29 June 2017), online: <www.theguardian.com/technology/2017/jun/28/canada-google-resultssupreme-court> [perma.cc/2B2R-EX4J]; Le Monde, "Google contraint par le Canada à déréférencer des liens à l'échelle mondiale" (29 June 2017), <www.lemonde.fr/pixels/ article/2017/06/29/google-contraint-par-le-canada-a-dereferencer-des-liens-a-l-echellemondiale_5152989_4408996.html> [perma.cc/5XFY-G6HL]. Criticism of the decision is discussed in Part I below.

11. Nazerali v Mitchell, 2018 BCCA 104 at paras 106-109. The British Columbia Court of Appeal upheld a global takedown order in an online defamation case issued prior to the Supreme Court's decision in Equustek but citing the latter case as a precedent to justify amending the order to allow for modifications in the event of a conflict of law. See also Autorité des marchés financiers v PlexCorps, 2017 QCTMF 88. An order of the Financial Markets Administrative Tribunal of Québec cited Equustek in an order against Facebook to remove pages of companies in contravention of provincial securities law. 
for debates about content takedown orders and for internet jurisdiction more broadly, it bears relevance to a range of stakeholders and merits closer analysis. ${ }^{12}$

Briefly, a lower court in this case imposed an injunction against Google, a third-party to litigation involving intellectual property infringement, to remove links directing traffic to the defendant's site not only from google.ca, but worldwide. ${ }^{13}$ The court imposed the order on the basis of finding that since Google was generating most of the traffic to the site, it was "inadvertently facilitating" the harm and de-listing from google.ca alone would not be effective. ${ }^{14}$ The Supreme Court upheld the global takedown order. The majority agreed that search engine links engage freedom of expression, but it declined to view links that direct a critical mass of users to infringing sites as protected speech. A court in California has since granted an injunction in Google's favour, precluding enforcement of the Canadian order in the United States on the basis that it conflicts with US law. ${ }^{15}$ In 2018, Google returned to court in British Columbia seeking to vary the global takedown order to exclude its application to Google in the United States, but the $\mathrm{BC}$ court dismissed the application. ${ }^{16}$ The Canadian takedown

12. Aside from the online commentary published in response to the Supreme Court's decision (canvased below), scholarly treatment of the case has thus far been brief or indirect and relates mostly to the lower court decisions. See e.g. Michael Rosenstock, "Is There a 'Right to Be Forgotten' in Canada's Personal Information Protection and Electronic Documents Act (PIPEDA)?" (2016) 14 CJLT 131; Krystyna Kowalik-Banczyk \& Oreste Pollicino, "Migration of European Judicial Ideas Concerning Jurisdiction over Google on Withdrawal of Information" (2016) 17 German LJ 315; Leslie E Minora, "U.S. Courts Should Not Let Europe's 'Right to Be Forgotten' Force the World to Forget" (2017) 89 Temp L Rev 609. On the Supreme Court's decision in Equustek see Slaine, supra note 5 at 371-72; Daskal, supra note 5, nn 130-32; Andrew Keane Woods, "Litigating Data Sovereignty" (2018) 128 Yale LJ 328, at 343-45, 375-78.

13. The facts and decisions are canvassed in more detail below.

14. Equustek Solutions Inc v Jack, 2014 BCSC 1063, Fenlon J [Equustek Solutions Inc].

15. Google LLC v Equustek Solutions Inc, 2017 US Dist Lexis 206818 (ND Cal 2017). This decision, along with a preliminary injunction issued the month prior, is discussed infra note 60 .

16. Equustek Solutions Inc v Jack, 2018 BCSC 610. Upon review of the December San Jose decision, Justice Smith declined to vary the global order partly on the basis that

[t]he U.S. decision does not establish that the injunction requires Google to violate American law. ... [T] here is no suggestion that any U.S. law prohibits Google from de-indexing those websites, either in compliance with the injunction or for any other reason. ... A party being restricted in its ability to exercise certain rights is not the same thing as that party being required to violate the law.

(Ibid at 20). He also found no material change in circumstances to justify varying the order. 
order continues to apply to Google worldwide, pending the outcome of the trial between the primary parties.

More broadly, the Equustek decision continues to serve as a key case in an emerging body of law on content takedown orders. Whether it proves to be an important precedent internationally remains to be seen. But courts and lawmakers, in Canada and beyond, will likely point to the decision as one viable solution to the larger problems with which it engages. The solution, however, is questionable in light of critical responses to the case (explored below) arguing that it failed to accord due weight to the speech interests of large intermediaries and the users who depend on them. Given the global interest the case has generated thus far, and its potential relevance to a wide range of debates about online speech, Part I of this commentary examines the decisions of the lower courts and arguments of the parties in some detail, along with the Supreme Court decision and critical responses to it. The intention here is to lend a better sense, for readers, both foreign and domestic, of the many contending strains of legal doctrine (equitable remedies, free speech, and defamation, among others) in which the parties sought to frame the core issues and to clarify the procedural context in which the global takedown order was fashioned and justified in the case. The general argument of Part I is that, at all levels of court, judges embraced a theory of linking as a form of facilitation premised on the fact that search links point a critical mass of users to harmful content. Embracing this view, courts at all levels failed to recognize the nature and importance of search links as a form of speech. ${ }^{17}$ Without seeing links that merely point to harmful content as warranting protection, or attempting to engage the issue in any depth, the courts largely overlooked the takedown order's broader implications for free speech online.

17. James Grimmelmann discusses the issue of search engine indexes as a form of speech, setting out the conduit, editorial, and advisor models. See "Speech Engines" (2014) 98 Minn L Rev 868. Eric Goldman, Eugene Volokh, and Donald M Falk, and Heather Whitney further discuss the models laid out in Grimmelmann. See Eric Goldman, "Search Engine Bias and the Demise of Search Engine Utopianism” (2006) 8 Yale JL \& Tech 188; Eugene Volokh \& Donald M Falk, "Google First Amendment Protection for Search Engine Search Results" (2012) 8 JL Econ \& Pol'y 883; Heather Whitney, "Search Engines, Social Media, and the Editorial Analogy" (February 2018), online: Knight First Amendment Institute at Columbia University <knightcolumbia.org/content/search-engines-social-media-and-editorial-analogy> [perma.cc/4GJ3-XH3P]. Similarly, Oren Bracha, Stuart Minor Benjamin, and Tim Wu explore whether algorithmic search results constitute speech. See Oren Bracha, "The Folklore of Informationalism: The Case of Search Engine Speech" (2014) 82 Fordham L Rev 1629; Stuart Minor Benjamin, "Algorithms and Speech" (2013) 161 U Pa L Rev 1445; Tim Wu, "Machine Speech" (2013) 161 U Pa L Rev 1495. 
Much of the critical response to the Supreme Court's decision to uphold the global takedown order was focused on the undervaluing of Google's expression interests. The criticism was largely silent, however, on an important tactical shortcoming on the part of Google and its sympathetic intervenors in the course of the litigation. A secondary aim of Part I is to show that while Google and free speech intervenors raised valid concerns about the potential impact of a global takedown order on speech, they failed to make clear why links to harmful content constitute valuable speech. This was a core question at all levels of court, and neither Google nor its allied intervenors succeeded in offering a clear and persuasive answer.

Part II of this commentary argues that an important source for the answer to this core question can be found in the Supreme Court's earlier decision in Crookes $v$ Newton, which set out a distinctly different theory of links as a form of speech. The Court in Crookes held that links to defamatory content are not a form of publication, due in part to their character as "mere references" but due also to the vital role links play in the function of the internet as a medium for the open exchange of information. In short, the answer Crookes offers to the search link problem in Equustek is that mere links to any content, harmful or not, are a valuable form of online speech because of their basic character as links. ${ }^{18}$ They serve a core function of the internet and any attempt to fashion categorical rules for their interference will necessarily have a broad impact on the medium. The Court should have applied its more considered view of links in Crookes to the case of search engines in Equustek on the basis that search links are, in principle, no different from other links and thus bear value. However, Equustek presented a new conundrum: At scale, links that merely refer can facilitate harm. What was needed, therefore, was a test that recognizes the value of links as such, but also the need in some cases to hold large portals responsible—-though not liable—for facilitating harm.

Part II then sets out a test for imposing extra-territorial takedown orders that attempts to strike a better balance between free speech and private interests. It draws on recent amendments to Canada's Copyright Act $(C A)$ and to the Manila Principles on Intermediary Liability, ${ }^{19}$ which both emphasize the principles of necessity and proportionality, set a high bar for takedown orders, and seek to

18. Crookes v Newton, 2011 SCC 47 at para 51 [Crookes].

19. CMA, supra note 6 (adding section 41.27 and other provisions to the Copyright Act, RSC, 1985, c C-42); Electronic Frontier Foundation, "Manila Principles on Intermediary Liability” (24 March 2015), online: <www.eff.org/files/2015/07/08/manila_principles_ background_paper.pdf\#page=19> [perma.cc/UBJ6-M9SG] [Manila Principles]. 
minimize their potential effects. The author applies this proposed test to the facts in Equustek itself, drawing on the dissenting opinion at the Supreme Court to support the view that the case would likely meet neither the necessity nor proportionality prong of the test. The commentary concludes by suggesting that a more equitable test would help address legitimate concerns that without greater protection of the speech interests of large platforms, the internet's function as a global public sphere will be significantly compromised.

\section{GOOGLE V EQUUSTEK}

\section{A. LOWER COURT DECISIONS}

As noted above, Google was a third-party to the core claim in this case. A series of interlocutory orders preceded the global takedown order that Google sought to challenge. The procedural context is relevant to the larger conflict over how to frame the core issues.

Equustek Solutions Inc. is a small technology company in British Columbia that makes networking devices for industrial equipment. ${ }^{20}$ In April 2011, Equustek sued its distributor, Datalink Technologies Gateways LLC (and its principal, Morgan Jack), for re-labelling one of Equustek's products and selling it as Datalink's own. Equustek also alleged that Datalink had used its trade secrets to develop and sell a competing product. In September 2011, Justice Leask of the Supreme Court of British Columbia issued an injunction against Datalink to remove references to Equustek products on its website and to return confidential source codes. In March 2012, Justice Fenlon found Datalink in breach of Justice Leask's order and issued a further order, but Datalink ignored this and fled the jurisdiction. In July 2012, Justice Punnett found that Datalink had continued to sell Equustek products online and issued a Mareva injunction ${ }^{21}$ for the seizure of Datalink's global assets. In August and September of that year, the court rendered further decisions prohibiting Datalink from selling the entire class of equipment at issue and finding Datalink's principal, Morgan Jack, to be in contempt.

In September 2012, with Jack and Datalink's whereabouts unknown and Datalink continuing to sell online, Equustek asked Google to remove listings of Datalink. Google would do so only with a court order and would de-list only individual pages but not entire sites. In December 2012, Justice Tindale issued an order prohibiting Datalink from "carrying on business through any

20. Equustek, supra note 1 at para 2.

21. Mareva Compania Naviera SA v International Bulkcarriers SA, [1975] 2 Lloyd's Rep 509 (CA) [Mareva]. 
website," ${ }^{22}$ and soon after Google advised Equustek that it had de-indexed some 345 webpages relating to Datalink, but only for searches on google.ca. Datalink continued to move infringing content to new pages on its sites.

In the fall of 2013, Equustek returned to court to seek an order that Google remove links to Datalink websites on all of its search portals worldwide. Google opposed the order on grounds familiar to those who have followed its earlier litigation..$^{23}$ Its index plays a "passive" role; it provides a "valuable tool" for helping people navigate the web, and an order forcing it to "arbitrate disputes over content" was impracticable at scale. ${ }^{24}$ An order to remove entire sites would also constitute "undue censorship," since some of the individual pages at a site might serve innocent purposes. ${ }^{25} \mathrm{~A}$ global injunction would also place Google in an "impossible situation" by asking it to do things that may be illegal in other jurisdictions. ${ }^{26}$ Finally, Google maintained that any order should be limited to google.ca, since courts in takedown cases against search engines have properly restricted the scope of their orders to regional or country-specific indexes, given the basis of the orders in national or regional law. ${ }^{27}$

Although Google offered several arguments against a global takedown order, its core claim - on which it would rely throughout the litigation-was that its search links play a neutral role in online speech. Google's links, even to harmful content, warrant protection because they merely refer to content rather than offer judgment or facilitate harm. As earlier scholarship has noted, online intermediaries had successfully relied on this framing in US cases as far back as the mid-90s, when the internet first emerged. ${ }^{28}$ Courts had developed a body of jurisprudence shielding intermediaries from liability for aiding in piracy or

22. Equustek, supra note 1 at para 14.

23. For the arguments advanced in earlier litigation, see Barry Sookman, "Is Google a Publisher According to Google? The Google v Equustek and Duffy Cases" (10 October 2017), online (blog): Copyright, Intellectual Property, Computer, Internet, e-Commerce Law <www. barrysookman.com/2017/10/10/is-google-a-publisher-according-to-google-the-google-vequustek-and-duffy-cases > [perma.cc/YCG3-WNZX].

24. Equustek Solutions Inc, supra note 14 at paras 136-37.

25. Ibid at para 138 .

26. Ibid at para 140. Notably, however, Google did not argue that a global takedown order would violate US law (see ibid at para 144).

27. Ibid at paras 145, 149 (discussing the decision in Mosley France). See also Mosley France, supra note 2.

28. See e.g. Jonathan Band \& Matthew Schruers, "Safe Harbors Against the Liability Hurricane: the Communications Decency Act and the Digital Millennium Copyright Act” (2002) 20 Cardozo Arts \& Ent LJ 295, citing Zeran v America Online, Inc, 129 F (3d) 327, 332 (4th Cir 1997); Blumenthal v Drudge, 992 F Supp 44 (DDC 1998); Religious Technology Center $v$ Netcom On-Line Communication Services, Inc, 907 F Supp 1361 (ND Cal 1995). 
publishing defamatory content by applying generously the prohibition in section 230 of the Communications Decency $A c{ }^{29}$ (CDA) on treating intermediaries "as the publisher or speaker of any information provided by another information content provider." ${ }^{30}$ In relying on the neutrality argument in this case, Google's counsel had therefore not simply sought to leverage the weight of US authority on point but also to engage a deeply entrenched jurisprudential conception of online portals as extensions of the internet's core infrastructure. While this conception may or may not have been plausible by the middle of the present decade, it might have led Google to be confident enough in the neutrality theory to have made it seem unnecessary to formulate a more nuanced response to the question: Why are links to harmful content worth protecting? ${ }^{31}$

From June 2014 onward, Google would discover that its neutrality argument would gain little traction in Canadian courts. That month, Justice Fenlon dismissed Google's arguments and issued an order requiring the company to "cease indexing or referencing" on any of its sites of any of the defendant's pages or subpages, pending the resolution of the case or further direction by the court. ${ }^{32}$ The court assumed jurisdiction over Google on the basis of its business operations in British Columbia. ${ }^{33}$ It claimed the authority to impose the order under its inherent jurisdiction to "maintain the rule of law and to control its own process." ${ }^{34}$ Yet, substantively, the order was based on two assumptions. The first was that since seventy to seventy-five per cent of all internet searches were conducted through Google, it was "inadvertently facilitating" the harm to the plaintiff by directing the bulk of traffic to the defendant's site. ${ }^{35}$ Justice Fenlon also found that " $[\mathrm{o}] \mathrm{n}$ the record before [him] it appears that to be effective, even within Canada, Google must block search results on all of its websites." ${ }^{36}$

29. Communications Decency Act of 1996, 47 USCA § 230 (1996) [CDA].

30. Band \& Schruers, supra note 28 at 297 (Band and Schruers' article also contains a useful summary of early cases relating to intermediary liability for online speech). For a more recent overview, see Corey Omer, "Intermediary Liability for Harmful Speech: Lessons from Abroad" (2014) 28 Harvard JL \& Tech 289, at 301-305.

31. I would like to thank an anonymous reviewer of this paper for noting this point.

32. Equustek, supra note 1 at para 17, citing Equustek Solutions Inc, supra note 14 at para 161.

33. Equustek Solutions Inc, supra note 14 at paras 22-65.

34. Ibid at para 121. The power, Fenlon J noted, is confirmed by section 39 of the Law and Equity Act, RSBC 1996, c 253. Justice Fenlon also cited MacMillan Bloedel Ltd v Simpson for the broader proposition that the court may issue an injunction "in all cases in which it appears to the court to be just or convenient that the order should be made ... on terms and conditions the court thinks just." [1996] 2 SCR 1048 at para 15.

35. Equustek Solutions Inc, supra note 14 at para 152.

36. Ibid at para 148 
The second key assumption was that links to a source of piracy could not constitute valuable speech and did not warrant protection. Justice Fenlon implied this by asserting that the order would not censor Google or "block what is being said," but was "only a slight expansion on the removal of individual URLs, which Google agreed to do voluntarily." ${ }^{37}$ It would involve minimal inconvenience to Google in light of removal requests it already carries out in relation to child pornography and hate-speech. ${ }^{38}$ Justice Fenlon made no attempt to consider the broader impact of a global takedown order on the expression interests of search engines or users. On the contrary, there were no serious potential expression or comity issues since, "most countries will likely recognize intellectual property rights and view the selling of pirated products as a legal wrong." ${ }^{39}$ The two assumptions that framed Justice Fenlon's justification for the global takedown order would continue to frame the Court's reasoning at the next two levels.

The Court of Appeal for British Columbia unanimously upheld the order. ${ }^{40}$ Justice Groberman (together with Justices Frankel and Harris) affirmed the lower court's in personam jurisdiction over Google for its commercial activity in the province. ${ }^{41}$ Under the test set out in RJR-MacDonald, ${ }^{42}$ the balance of convenience favoured issuing the order. Justice Groberman dismissed the comity issue by asserting a similar faith in the wider moral basis for the order; as a measure intended to prevent piracy, he asserted, "there is no realistic assertion that the judge's order will offend the sensibilities of any other nation." 33

What is notable about the Court of Appeal's decision was that it glossed over important distinctions in the case law on equitable remedies on which it drew for support. Justice Groberman cited a host of cases for the broad proposition that "courts of many other jurisdictions have found it necessary, in the context of orders against Internet abuses, to pronounce orders that have international effects." ${ }^{44}$ Yet he made no effort to distinguish the scope of these orders, or the

37. Ibid at para 137.

38. Ibid at para 139.

39. Ibid at para 144 .

40. Equustek Solutions Inc v Google Inc, 2015 BCCA 265 [Equustek BCCA].

41. Ibid at paras 52-53.

42. RJR-MacDonald Inc v Canada (Attorney General), [1994] 1 SCR 311. See supra note 40 at paras 100-107. The defendant's acts were held to cause the plaintiff irreparable harm; an order with only a national scope would not be effective; and Google would not be materially inconvenienced.

43. Equustek BCCA, supra note 40 at para 93. An important proviso limiting the scope of the order, however, was that Google was free to return to court in British Columbia (see e.g. ibid at para 94).

44. Ibid at para 95 . 
nature of the cases on which they were based. Many had involved reputational harm rather than property (e.g., the Mosley cases, McKeogh, Google Spain), and some involved regional orders or orders against parties hosting rather than pointing to content (Yahoo! Inc and the German Mosley cases are examples of both). Thus, none of the cases served as a clear precedent. Citing them as supportive authorities prevented the court from recognizing both the novelty and the magnitude of the lower court's order in relation to earlier case law in the broader field of intermediary liability.

At the Supreme Court of Canada, Google made a further attempt to foreground the expression interests at stake in the order. It did so by offering two general arguments in relation to search engine links as a form of speech. One had more potential than the other. Neither proved persuasive to the majority, perhaps in part because Google appeared to blur them together. ${ }^{45}$

The more promising argument was that while there may have been a justification for limiting Datalink's speech, there was no principled basis on which to limit that of a search engine merely pointing to it. ${ }^{46}$ Doing so also ran contrary to the Court's holding in Crookes $v$ Newton.$^{47}$ In that case, links in journalistic articles on one site to defamatory content on another were held to engage free expression, and the defamatory nature of the content did not "defeat" the defendant's right to link to it. ${ }^{48}$ As Google noted, the Court's rationale in Crookes was premised on a recognition of the importance of hyperlinks to the internet's function as an information medium and a concern about a potentially "devastating" chill on free expression if users merely linking were held liable for defamation. ${ }^{49}$

The argument amounted to an attempt to reframe the central question in the case. Google was implying that the Court should not ask what value, as a form of speech, a single link might have to an infringing site. Rather, the Court should have asked what value links per se have as part of the internet's infrastructure. However, while Google was on firm ground in appealing to the Court's earlier jurisprudence on linking, it might have been more explicit on the

45. Google Inc v Equustek Solutions Inc, 2017 SCC 34 (Factum of the Appellant, Google Inc at paras 40-45) [Google Factum] (the blurring to which I refer occurs in the discussion of the Court of Appeal's "three key errors in evaluating the interest of freedom of expression").

46. Ibid at paras 27-29.

47. Crookes, supra note 18.

48. Google Factum, supra note 45 at para 32.

49. Ibid at para 31, 41. The Google Factum draws further support for this proposition from Crookes, which states: "The Internet's capacity to disseminate information has been described by this Court as 'one of the great innovations of the information age' whose 'use should be facilitated rather than discouraged' (SOCAN, at para 40, per Binnie J.). Hyperlinks, in particular, are an indispensable part of its operation." Supra note 18 at para 35. 
nature of the shift in perspective it was inviting the Court to undertake. Instead, the argument on this point was relatively brief and undeveloped. It was also advanced without being distinguished from a second, less promising argument: Google as a neutral actor.

Despite Google's lack of traction for this argument in the lower courts, it argued once again that its search engine links were a valuable form of speech because its primary aim as a speaker is to offer a neutral "catalogue" of the content of cyberspace. The more accurate and complete the catalogue, the better it serves users in pursuing a range of possible purposes and the free exchange of information more broadly..$^{50}$ Justice Fenlon's order instead "compel[led] Google to intentionally mislead users worldwide ... about the existence of relevant and publicly accessible websites," impeding the "public's right to access information." ${ }^{1}$ The trouble with this argument, however, was that while it was clear that providing a catalogue is important, it was not clear how the catalogue's links to sites that engage in piracy constitute the provision of "relevant" information. It was unclear, that is, how such speech served the underlying purposes that justify the freedom of expression — truth seeking, self-fulfillment, and political engagement. ${ }^{52}$

A third line of attack concerned equitable remedy law. Google argued that the order exceeded the scope of the relief contemplated in the case law on injunctions on which the Respondent had relied. ${ }^{53}$ Cartier, a case on which the Court of Appeal

50. Google Factum, supra note 45 at para 42.

51. Ibid at para 41 .

52. Irwin Toy Ltd $v$ Quebec (Attorney General), [1989] 1 SCR 927 at 976 [Irwin Toy], citing Ford $v$ Quebec (Attorney General), [1988] 2 SCR 712 at 765-67 [Ford]. In the former, Chief Justice Dickson summarizes the discussion in the latter, writing that the objectives of the right to free speech are: "(1) seeking and attaining the truth is an inherently good activity; (2) participation in social and political decision-making is to be fostered and encouraged; and (3) the diversity in forms of individual self-fulfillment and human flourishing ought to be cultivated in an essentially tolerant, indeed welcoming, environment."

53. Google Factum, supra note 45 at para 69-88, citing Mareva, supra note 21; Norwich Pharmacal Co v Comrs of Customs and Excise, 1974 AC 133 [Norwich]; Cartier International AG et al v British Sky Broadcasting Ltd et al, 2014 EWHC 3354 [Cartier HC]; RJR-MacDonald, supra note 42. Google argued that the injunction in RJR-MacDonald was ordered against a party to the litigation to preserve a potential remedy against them, whereas Google in this case is not a party. Additionally, Google argued that the Norwich orders compel third parties to provide information to assist a wronged party, and not to "deputize innocent third parties in an effort to assist frustrated plaintiffs dealing with defendants who are in contempt." Google Factum, supra note 45 at para 70. Further, Google argued that Cartier involved an injunction against an internet service provider in a copyright infringement case to block access to an infringing site, but the order was limited to two years and limited geographically ... and furthermore Mareva injunctions pertain to "commercial entities such as banks, brokerage houses and the like," which hold the defendant's property and not merely one means of access to it, as in this case. Google Factum, supra note 45 at para 85 . 
had placed much emphasis, involved an order against a group of internet service providers (ISP) to block users from accessing websites of a trademark infringer. ${ }^{54}$ However, as Google noted, the court in Cartier did not rely on Norwich or other common law authority, but on a European Enforcement Directive ${ }^{55}$ allowing for injunctive relief in intellectual property cases where it was fair, equitable, and proportionate. ${ }^{56}$ Justice Arnold, for the High Court for England and Wales in Cartier, held that among the factors for assessing proportionality was the efficacy of the measures at issue and their impact on the "fundamental rights" of other net stakeholders, including "ISP's freedom to conduct business" and the "freedom of information of internet users." ${ }^{57} \mathrm{He}$ also explicitly considered imposing a removal order against search engines as an alternative to an order against the ISPs in this case, but declined to do so. He observed that while it might be possible to issue such an order in a privacy-related case, "it is not at all clear at present that any EU court would have power to order de-indexing on the basis of intellectual property infringement." 58

Finally, Google argued that the lower courts were wrong in their assessment of the comity issue. The order was at least "legally impermissible" and "contrary to public policy" in the United States. ${ }^{59}$ Section 230 of the $C D A^{60}$ provides search engines and other online intermediaries with broad immunity for liability from injunctive or monetary relief for acting as publishers. ${ }^{61}$ Appellate courts have taken a broad view of the scope of this protection. ${ }^{62}$ The order here did not entail a finding of liability but it was premised on treating Google as a publisher

54. Cartier HC, supra note 53.

55. EC, Directive 2004/48/EC of the European Parliament and of the Council of 29 April 2004 on the enforcement of intellectual property rights [2004] OJ, L 195/16, art 11 [EC Directive], cited in Cartier HC, supra note 53 at para 83.

56. Google Factum, supra note 45 at para 77.

57. Cartier HC, supra note 53 at paras $183,188$.

58. Google Factum, supra note 45 at para 79, citing Cartier HC, supra note 53 at para 212.

59. Ibid at para 91.

60. CDA, supra note 29.

61. Ibid.

62. Zeran v America Online Inc, 129 F (3d) 327 (4th Cir 1997); Blumenthal v Drudge, 992 F Supp 44 (DDC 1998); Kathleen Rv City of Livermore, 87 Cal (4th) 684 (App Ct 2001); Doe v MySpace Inc, 528 F (3d) 413 (5th Cir 2008). See also Jeff Kosseff, "Twenty Years of Intermediary Immunity: The US Experience" (2017) 14 Scripted 5 at 9. An important recent limit to section 230 is US, Bill HR 1865, Allow States and Victims to Fight Online Sex Trafficking Act of 2017, 115th Cong (recently passed in both the House and Senate). Section 4 of the Act amends section 230 of the $C D A$, supra note 29 by adding a provision allowing for intermediary liability for promotion or facilitation of prostitution. 
(“inadvertently facilitating," in Justice Fenlon's words) contrary to section $230{ }^{63}$ This was a compelling argument-one that a majority of the Supreme Court in Equustek expressed doubt upon but did not reject entirely, and one that a US court (reviewing the order in this case) has now accepted. ${ }^{64}$ An important exception to intermediary immunity in section 230 is immunity from intellectual property claims. ${ }^{65}$ Soon after passing the $C D A$, Congress passed the Digital Millennium Copyright Act $(D M C A)^{66}$ to provide a notice and takedown scheme that shields an online provider from liability if they act in a timely fashion and remove infringing material. But the DMCA appears to contemplate situations in which the online provider hosts or publishes content, not where they merely link to it. Thus, the

63. Google Factum, supra note 45 at paras 98-100.

64. Following the Supreme Court of Canada's decision in this case, Google sought an injunction in California on the basis that the order cannot be enforced in the United States as contrary to the First Amendment and section 230 of the Communications Decency Act (CDA). See $C D A$, supra note 29. In November of 2017, a US District Court in San Jose granted a preliminary injunction on the basis that Google had demonstrated a likelihood of success on the merits of its claim with regard to the $C D A$ (but declined to consider the First Amendment). Equustek did not appear. The court found the Canadian order to be contrary to section 230 of the $C D A$ on the basis that Google met the three-part test for immunity under the provision: Google provides an "interactive computer service"; the information at issue was "provided by another information content provider"; and the Canadian order "would hold it liable as the 'publisher or speaker' of that information." See Google LLC v Equustek Solutions Inc, 2017 US Dist Lexis 206818 at 2 (ND Cal 2017). However, the 6-page decision contains no discussion of the limits of section 230, and in particular its explicit exclusion for immunity of intellectual property claims (230(c)(1)). The Court has since issued a permanent injunction in a default judgment in Equustek's favour. Google LLC v Equustek Solutions Inc, 2017 US Dist Lexis 182194 (ND Cal 2017). For a critical response to the preliminary injunction, see Barry Sookman, "US Court Thumbs Its Nose at Supreme Court of Canada: Google v Equustek” (19 November 2017), online (blog): Copyright, Intellectual Property, Computer, Internet, e-Commerce Law <www.barrysookman. com/2018/02/18/us-court-thumbs-its-nose-at-supreme-court-of-canada-google-v-equustek> [perma.cc/R26J-CAAH]. Sookman argues that the court here mistakenly construed the scope of immunity under section 230, citing case law to the effect that "treating as a publisher" means seeking to hold liable in tort. See also Michael Geist "U.S. Judge Rules Canadian Court Order 'Threatens Free Speech on the Global Internet" (3 November 2017), online (blog): Michael Geist <www.michaelgeist.ca/2017/11/googleequustekinjunction> [perma.cc/ LJA4-FH4F]. Geist sees the injunction as confirmation of the short-sightedness of Fenlon J's decision to impose the order in failing to foresee the inevitability of protracted litigation abroad, leading to conflicting decisions.

65. See CDA, supra note 29. S 230(e)(2) states: "Nothing in this section shall be construed to limit or expand any law pertaining to intellectual property."

66. Digital Millennium Copyright Act, Pub L No 105-304, § 512, 112 Stat 2860 (1998) (codified as amended at 17 USC (2000)) [DMCA]. 
question of whether the immunity in section 230 of the $C D A$ protects a search engine from merely linking to an infringing site is unclear. ${ }^{67}$

Google also pointed to the First Amendment as a basis on which the order might violate comity. It cited case law recognizing search engine listings as constitutionally protected speech, ${ }^{68}$ and cases on First Amendment protection for the mere provision of information. ${ }^{69}$ However, Google did not cite a case in which the First Amendment was held to protect a search engine or online intermediary's right to point to a property-infringing site. ${ }^{70}$

One further concern in relation to comity worth noting was the possible effect of the order as a precedent. Google noted that Justice Fenlon's order was not premised on a finding that any of the plaintiff's property rights outside of Canada had been violated. It may have been based on the notion that an order ultimately intended to prevent piracy would not be morally objectionable to any

67. Google Factum, supra note 45 at para 98. Google asserted that "American courts have repeatedly applied [section 230 of the $\mathrm{CDA}$ ] to bar claims for monetary or injunctive relief against Internet search engines (including Google) for merely providing links to third-party websites that contain objectionable or unlawful information." It also cited two cases for this proposition: Parker v Google and Murawski v Pataki. Neither case deals with a mere link. Parker $v$ Google concerns whether Google's caching of copyrighted material constituted infringement. 422 F Supp (2d) 492 (ED Penn 2006). In Murawski v Pataki, the plaintiff had taken issue with the association of his name in Ask.com's search results with the Communist Party. 514 F Supp (2d) 577 (SDNY 2007).

68. Google Factum, supra note 45 at para 96, citing Jian Zhang et al v Baidu.com Inc, 10 F Supp (3d) 433 (SDNY 2014); Yahoo Inc v La Ligue Contre le Recisme et L'Antisemitisme, $169 \mathrm{~F}$ Supp (2d) 1181 (ND Cal 2001), rev'd on other grounds 145 F Supp (2d) 1168 (ND Cal 2001). On this point, see also Eric Goldman, "Of Course the First Amendment Protects Google and Facebook (and It's Not a Close Question)” (2018) 9 Santa Clara L Rev 1 at 2-3.

69. Google Factum, supra note 45 at para 96, citing Sorrell et al v IMS Health et al, $131 \mathrm{~S} \mathrm{Ct}$ 2653 at 2667 (US Sup Ct 2011) [Sorrell]. Sorrell involved a challenge to a statue prohibiting the publication of the prescription practices of doctors in Vermont. Justice Kennedy for the majority, held at 2667, that "the creation and dissemination of information are speech within the meaning of the First Amendment. Facts, after all, are the beginning point for much of the speech that is most essential to advance human knowledge and to conduct human affairs."

70. See Hermès, supra note 7; Chanel, supra note 7; Richemont, supra note 7; ABS-CBN, supra note 7; American Chemical, supra note 7. It is suggested that US courts, in cases where global orders against search engines were imposed, have not assumed that a takedown order against a search engine is precluded by the First Amendment. In each of these cases, however, the orders extended to search engines incidentally (in each case, search engines are effectively mentioned in passing); no engine was a party to any of the proceedings. 
reasonable court. However, this would likely invite other courts to issue similar orders based on differing views of what is reasonable. ${ }^{71}$

A host of intervenors supported Google's position. ${ }^{72}$ Much of the argument focused on the need to accord free expression a greater role in the test for granting a takedown order. A number of the intervenors argued that it was inappropriate to apply the balance of convenience test in RJR-McDonald without modification, suggesting additional requirements such as necessity, proportionality, and minimal impairment. ${ }^{73}$ All of them shared a concern that the order would serve as an invitation to courts in illiberal regimes to impose global orders based on different values.

One thread worth highlighting among these submissions was the attempt to address the core issue in the case: Why should links pointing to a site that engages in piracy be considered valuable speech? The Canadian Civil Liberties Association drew a distinction between the value of the particular communication here (a link to an infringing site) and the nature of search engine speech as a form of commercial expression. ${ }^{74}$ The Court of Appeal had assessed the order without according due weight to expression involving commercial speech, which the Supreme Court has recognized in the past. ${ }^{75}$ A group of news entities calling itself the "Media Coalition" argued that the Court of Appeal had taken too narrow a view of the expression interests by asking only whether an order to block links to the defendant's site in this case would offend the values of any nation. ${ }^{76}$ This overlooked the free expression rights of the public and the press, who use search links for "newsgathering and accurate reporting purposes." ${ }^{\text {" Th }}$ The order in this case impeded one possible innocent use of the links: The media reporting on

71. See Google Factum, supra note 45 at para 107. Google asked:

Should Turkey grant orders prohibiting Canadians from finding and reading political commentary written about its former Prime Minister Ataturk? Should Russia grant orders prohibiting Canadians from finding and reading websites that contain anti-Kremlin content? Should Thailand grant orders prohibiting Canadians from finding and watching videos critical of the King of Thailand? Failure to limit the scope of a remedial interlocutory injunction to Canada's territorial boundaries puts Canadian citizens at risk of overbroad orders made in other countries that do not share our commitment to freedom of speech.

72. See e.g. Google Inc v Equustek Solutions Inc, 2017 SCC 34 (Factum of the Reporters Committee for Freedom) [Reporters Factum].

73. See e.g. Google Inc v Equustek Solutions Inc, 2017 SCC 34 (Factum of the Electronic Frontier Foundation at para 28); Google Inc v Equustek Solutions Inc, 2017 SCC 34 (Factum of the British Columbia Civil Liberties Association at para 4).

74. Google Inc v Equustek Solutions Inc, 2017 SCC 32 (Factum of the Intervener Canadian Civil Liberties Association at para 23).

75. Ibid at para 24 .

76. Reporters Factum, supra note 72 at para 26.

77. Ibid at para 28. 
Equustek or Datalink. Without search engine links, journalists would "not be able to find the Defendants' websites unless [they] happened to know the exact website addresses." ${ }^{78}$ Search links to potential sources of piracy or other kinds of harm thus bear at least some value that should be weighed in the balance.

In its response, Equustek contested Google's claim that the order amounted to a form of censorship. "Google's censorship thesis," it argued, "was not anchored in any legal framework"79 and Google had notably not made a Charter claim in this case. On the contrary, Google had asked Equustek to obtain the order and was simply taking issue with its extra-territorial scope. Justice Fenlon had rejected the censorship argument precisely on the basis that Google had recognized the need for takedowns in many cases and had a large staff and processes in place to address this. ${ }^{80}$ Equustek also contended that none of the recognized purposes of free expression in Irwin Toy ${ }^{81}$ or Ford ${ }^{82}$ - self-fulfillment, truth seeking, or the exchange of ideas for political discourse - were advanced by a link that pointed to an IP-infringing site. ${ }^{83}$ Nor was it appropriate to apply the tests set out in cases dealing with journalists' sources or publication bans, given the focus in those cases on the personal liability of journalists and the open court principle. ${ }^{84}$

Equustek's framing of the issues was in large part an exercise in rhetorical finesse that kept the focus of attention on the links at issue and on the notion of Google as a facilitator. Lost or elided here was the larger significance of forcing a neutral third-party such as Google from removing any kind of content that merely points, regardless of what it happens to point to. Also lost here were important distinctions between the nature of and reasons for the takedowns that Google voluntarily conducts, or the court orders it invited Equustek to seek. Some removals are in response to corporate policies against hate speech or child pornography, but many others are in response to requests under legislation, such as the DMCA, that call for removal in intellectual property cases where Google hosts or serves the content at issue, rather than merely linking to it. And the order Google invited the plaintiff to seek here was for a removal intended to be regional in scope. The global order in this case did not simply mandate what Google already does voluntarily.

78. Ibid.

79. Google Inc v Equustek Solutions Inc, 2017 SCC 32 (Factum of the Respondent at para 84) [Equustek Factum].

80. Ibid.

81. Irwin Toy, supra note 52.

82. Ford, supra note 52.

83. Equustek Factum, supra note 79 at para 88.

84. Ibid at paras 93-94. 
Intervenors representing music, film, and publishing industry groups offered further support for Equustek's position. ${ }^{85}$ They argued that a reluctance on the part of courts to impose orders against search engines and other intermediaries where they facilitate or are otherwise "sufficiently 'mixed up' in illegal activities" would significantly hinder the "effectiveness of law online," making it vastly more difficult to curb hacking, privacy breaches, defamation, terrorism, and intellectual property theft, among other acts. ${ }^{86}$ An order against a search engine is often more practical and effective than forcing the affected party to bring proceedings in every place the engine operates or the wrong occurs. ${ }^{87}$ Content takedown orders have begun to be used with some frequency in Europe and the United States and are consistent with principles underlying orders against non-parties. ${ }^{88}$ Canadian courts have ordered Google to de-list in the past, ${ }^{89}$ and in the United Statescontrary to Google's argument that such orders are precluded under US law-a number of courts have issued global de-listing orders in IP-infringement cases. ${ }^{90}$ Concerns on the part of Google and free speech groups were overstated here since "no legitimate expressive values were engaged" by Google's links. ${ }^{91}$

\section{B. SUPREME COURT DECISION}

In a 7 to 2 decision, the majority of the Supreme Court dismissed Google's appeal, favouring the way Equustek and its sympathetic intervenors had framed the issues, along with the lower courts. ${ }^{92}$ Writing on behalf of the majority, Justice Abella dismissed Google's argument that the order entailed an improper extension of injunction law, affirming much of Justice Groberman's analysis, including his

85. Google Inc v Equustek Solutions Inc, 2017 SCC 34 (Factum of the Interveners International Federation of the Phonographic Industry et al) [Phonographic Industry Factum]; Google Inc $v$ Equustek Solutions Inc, 2017 SCC 34 (Factum of the Intervenors International Federation of Film Producers Associations et al) [Film Producers Factum].

86. Phonographic Industry Factum, supra note 85 at paras 9-10.

87. Ibid at para 10; Film Producers factum, supra note 85 at paras 24-25.

88. Phonographic Industry Factum, supra note 85 at para 11. See e.g. APC v Orange, supra note 6; APC v Auchan Telecom SAS, Paris Reg Ct case no 11/60013 (November 28, 2013); PJS v News Group Newspapers [2016] UKSC 26.

89. Phonographic Industry Factum, supra note 85 at para 11. See e.g. Nazerali v Mitchell, 2011 BCSC 1581; Langlois v Google Canada, 2014 QCCS 6507.

90. Phonographic Industry Factum, supra note 85 at para 11. See e.g. Hermès, supra note 7; Chanel, supra note 7; ABS-CBN, supra note 7; American Chemical, supra note 7.

91. Phonographic Industry Factum, supra note 85 at para 21. See also Film Producers Factum, supra note 85 at para 37. It states, "[w] here political speech is at issue, freedom of expression values are likely to weigh against granting such an order. This case, however, falls on the opposite side of the spectrum; the Order concerns purely commercial speech promoting unlawful products, contrary to court orders and infringing others' legal rights."

92. Equustek, supra note 1. 
reliance on Cartier for the application of an injunction to an online intermediary in a property infringement case. ${ }^{93}$ As the Court of Appeal had done, the majority here failed to distinguish that the order in Cartier was issued not on the basis of the common law on injunctions but under a European Enforcement Directive ${ }^{94}$ and that the court in Cartier had considered imposing an order against search engines but expressly declined to do so as excessive. ${ }^{55}$ Assuming that Norwich and other common law authority properly extended to search engines in a case of this nature, Justice Abella held that the balance of convenience in RJR-MacDonald favoured a global injunction on the basis of both effectiveness and principle. ${ }^{96} \mathrm{Key}$ for Justice Abella was Justice Fenlon's finding that in the "absence of de-indexing ... Google was facilitating Datalink's breach" of court orders. ${ }^{97}$ The majority also agreed with Justice Fenlon's finding (and Google's concession) that Datalink could not "carry on business in a commercially viable way unless its websites were in Google's search results" ${ }^{\text {" }}$ and that "to be effective, even within Canada, Google must block search results on all of its websites." ${ }^{\text {"9 }}$ Characterizing the issue in broader terms, Justice Abella wrote: "The problem in this case is occurring online and globally. The Internet has no borders-its natural habitat is global. The only way to ensure that the interlocutory injunction attained its objective was to have it apply where Google operates—globally." 100 Justice Fenlon had also found that "the majority of Datalink's sales take place outside Canada" and thus, Google's suggestion that the order be limited to Canada would fail to prevent much of the harm at issue. ${ }^{101}$ Justice Abella concluded that "Google would still be facilitating Datalink's breach of the court's order" if it continued to index sites on its non-Canadian portals; there was thus "no equity in ordering an interlocutory injunction which has no realistic prospect of preventing irreparable harm." ${ }^{102}$

The majority's response to the comity and free-speech issues was brief. Justice Abella characterized Google's assertion that the global order might require it to

93. Ibid at para 32 .

94. EC Directive, supra note 55, arts 1,2.

95. Equustek, supra note 1 at paras 31-33; Cartier HC, supra note 53 at paras 211-12.

96. Equustek, supra note 1 at paras 25-35, citing RJR-MacDonald, supra note 42.

97. Ibid at paras 34-35. The Court states:

Much like a Norwich order, or a Mareva injunction against a non-party, the interlocutory injunction in this case flows from the necessity of Google's assistance in order to prevent the facilitation of Datalink's ability to defy court orders and do irreparable harm to Equustek. Without the injunctive relief, it was clear that Google would continue to facilitate that ongoing harm.

98. Ibid at para 34 .

99. Ibid at para 40.

100. Ibid at para 41 .

101. Ibid.

102. Ibid at para 41. 
violate the law of a foreign jurisdiction as "theoretical." ${ }^{103}$ Moreover, the order would not likely give rise to a conflict of law, since it was based on the illegality of piracy and "most countries" would "view the selling of pirated products as a legal wrong." "104 There was no attempt here to parse the distinct roles of Datalink and Google or differences in the value of their speech. Both Datalink's sites and Google's mere indication of their whereabouts were forms of piracy on this view. This is not to say that the traffic Google generates in pointing to Datalink is not important to assessing the degree to which Google's speech should be protected. However, Justice Abella's analysis glossed over these issues.

Justice Abella also noted that Google had not adduced evidence before Justice Fenlon on the conflict of law issue. Without this, it "hardly seem[ed] equitable to ... put the onus on [Equustek] to demonstrate, country by country, where such an order is legally permissible." ${ }^{105}$ Justice Abella conceded that Google's index is a form of speech, but links that facilitate piracy do not warrant protection:

This is not an order to remove speech that, on its face, engages freedom of expression values, it is an order to de-index websites that are in violation of several court orders. We have not, to date, accepted that freedom of expression requires the facilitation of the unlawful sale of goods. ${ }^{106}$

The majority had thus asserted that the links here possessed no value as speech and warranted no protection whatsoever. If any balancing of interests was to be undertaken in assessing the order, it was not between Google's speech and the harm to the plaintiff. It was between the inconvenience to Google in removing the links and the inconvenience to the plaintiff in attempting to shut down Datalink's business in other ways. The balancing engaged here not only failed to consider Google's speech rights, but it also ignored the right of a wider public to access information. Put differently, by asserting that a link that merely points to harmful content forfeits any protection as a form of speech, the majority was not simply affirming an order in relation to the single link in this case-it was sanctioning a broader practice in which courts in one jurisdiction could decide what a global public can or cannot access. There may indeed be good reason for doing so-e.g., removing links to a video of an attack posted by a terrorist him-or herself. Nevertheless, the point is that where this occurs, speech interests are clearly engaged.

Justice Abella's reasoning in relation to the nature of Google's links here mirrored the pattern of both courts below. Pointing to a site alleged to be the

103. Ibid at para 44 .

104. Ibid. See also Equustek Solutions Inc, supra note 14 at para 144.

105. Ibid at para 47.

106. Ibid at para 48 . 
source of piracy sufficed to make one's links a form of facilitation, where the pointing generates a large amount of traffic. The link, therefore, has little if any value as speech and does not amount to censorship. ${ }^{107}$ The majority opinion makes no reference to Crookes. It contains no discussion of how its approach to hyperlinks contrasts with the Court's earlier view—or attempts to offer any further justification aside from implying that by generating a critical mass of visitors, search links are qualitatively different from those contemplated in Crookes.

Justice Abella also justified the order in light of the fact that it does not compel Google to do something it does not already do: "[A]lter search results" by removing links to child pornography, hate speech, or requests in compliance with the $D M C A .{ }^{108}$ Justice Abella did not refer to the $C D A$ and did not offer any response to Google's contention that Section 230 of that Act precluded the kind of order at issue here. By invoking the $D M C A$ without reference to the $C D A$, Justice Abella was suggesting that the order in this case was a parallel form of relief to that available under the $D M C A$ and not an infringement of the $C D A$. But as noted above, the $D M C A$ pertains to copyright infringements that occur where intermediaries host the content at issue and not where they merely point to it.

However, Justice Abella seemed tentative in her assessment of the comity issue, at least in relation to the US, and concluded this part of the discussion by noting that the order allowed Google to return to court if a conflict did arise with foreign law, "including interfering with freedom of expression." 109 The majority's opinion contains no further discussion or acknowledgement that speech online might be affected by the order and no attempt was made to weigh the importance of Google's, or other internet users', interests against those of the plaintiff in issuing the order.

Writing in dissent, Justices Côté and Rowe held that Justice Fenlon's order was not lawfully issued and should be overturned. In their view, the injunction was effectively permanent in this case on the basis that by removing Datalink sites from all of Google indexes, Datalink would be put out of business. Yet the plaintiff would not have met the test for a permanent injunction. ${ }^{110}$ This would require "a more extensive review of the merits of the case" (an assessment

107. Ibid at para 49. Abella J states: "I have trouble seeing how this interferes with what Google refers to as its content neutral character" since the order did not require Google to "monitor content" or hold it liable for "facilitating access to the impugned website."

108. Ibid at para 50.

109. Ibid at para 46.

110. Ibid at para 56. 
of whether the alleged piracy had taken place), a matter not fully settled by the statements of defence that had been struck. ${ }^{11}$

More crucial for the present purposes was the dissent's view of the necessity and effect of the order. It was imposed not primarily to protect Equustek, but to address Datalink's failure to abide by earlier orders that it abstain from doing business online. The harm at issue was thus not the improper use of Equustek's intellectual property, but the harm to the court in Datalink's thumbing its nose at the court by posting new sites in breach of its orders. As Justices Côté and Rowe asserted:

Google did not aid or abet the doing of the prohibited act. ... the December 2012 Order was to cease carrying on business through any website. That Order was breached as soon as Datalink established a website to conduct its business, regardless of how visible that website might be through Google searches [emphasis added]. ${ }^{112}$

If Justice Fenlon's order had a lawful basis, then, it was to enjoin Google as a facilitator of Datalink's effort to conduct business. Yet this was clearly excessive:

If Equustek's argument were accepted, the scope of "aids and abets" would, in our view, become overbroad. It might include the companies supplying Datalink with the material to produce the derivative products, the companies delivering the products, or as Google argued in its factum, it might also include the local power company that delivers power to Datalink's physical address. ${ }^{113}$

Taking this view of the order, Justices Côté and Rowe had no cause to engage in a larger theory of links as a form of speech or to consider the broader impact of the order in terms of free expression. Google, and the traffic it happens to generate, was simply not the appropriate subject of the court's concern.

Turning to the issue of Google's relationship to Equustek, Justices Côté and Rowe asserted: "The most that can be said is that the Google Order might reduce the harm to Equustek which Justice Fenlon found 'Google is inadvertently facilitating."." 114 Yet, "it has not been shown that the Google Order is effective in doing so." 115 Datalink could still be found through other engines and could

111. Ibid at para 56, citing RJR-MacDonald, supra note 42 at 338-39. The case proposes that an injunction is effectively permanent "when the result of the application will impose such hardship on one party as to remove any potential benefit from proceeding to trial," in which case "a more extensive review of the merits of the case must be undertaken."). The appropriate test for granting a permanent injunction is found later in the dissent. See also Equustek, supra note 1 at para 66.

112. Ibid at para 71 .

113. Ibid.

114. Ibid at para 79. See also Equustek Solutions Inc, supra note 14 at para 152.

115. Ibid. 
continue to operate, suggesting that the lower court should have proceeded with greater caution. There were also other remedies available here. The Court of Appeal had suggested the plaintiff seek a remedy against the defendants in French courts, on the understanding that the defendants may have assets in France. ${ }^{116}$ Equustek might also have sought an order against the ISP hosting Datalink's sites, as was done in Cartier. ${ }^{117}$

The two opinions in Equustek were thus premised on differing views about the nature of the order and Google's role in relation to it. For the majority, the order was primarily meant to spare the plaintiff from further harm and grounded in the court's authority to issue injunctions to protect its own process. However, the majority's view of Google's links, as a form of facilitation based on the traffic they generate, led it to minimize the speech interests at issue. The dissent avoided this problem by framing the order in terms of a different harm (Datalink's business) and casting Google's role in it as peripheral. Lost in the Court's debate over the legitimacy of the order was the core substantive question in the case-are Google's links to a source of piracy a form of valuable speech? Following the lower courts, the majority took the view that they are not, but Justice Abella made no attempt to defend this view. It was a question not far from the central issue in the Court's earlier decision in Crookes.

\section{CRITICAL RECEPTION}

Before turning to Crookes, critical responses to the Supreme Court's decision in Equustek are worth canvasing briefly, for two reasons. They shed further light on why global takedown orders may in some cases be necessary and why they give rise to broader concerns in relation to freedom of expression and the rule of law. A better sense of these concerns is relevant to crafting a more nuanced and equitable test for takedown orders (see Part II below). Responses to Equustek also help shed light on a certain impasse in the larger debate about content takedown orders. Critics hold contrary assumptions about whether links to harmful content bear value, but they tend not to articulate and defend those assumptions. This too is important context for the discussion in Part II. I seek to make the point here that the debate about Equustek, and takedown orders generally, has tended to be polarized precisely because it does not rest on a clear sense of how or why links to harmful content may or may not be valuable.

116. Ibid at para 81, citing Equustek Solutions v Jack, 2016 BCCA 190 at para 24

[Equustek v Jack].

117. Ibid 1 at para 81 . 
Copyright and intellectual property advocates lauded Equustek for recognizing the need for more effective recourse against intermediaries that assist in property infringement. Counsel for one of the intervenors in the case, Barry Sookman, affirmed the decision as a lesser of two evils. ${ }^{118}$ Content takedown orders may intrude on search engine speech, but neither voluntary gestures on the part of search portals, nor individual demands under legislation such as the $D M C A,{ }^{119}$ offer the same practical benefits. They often result in de-listings of only some of the impugned content and only on national portals. Nor is litigation in all the jurisdictions in which intermediaries operate a viable solution. ${ }^{120}$ Equustek is part of a larger trend in which courts are beginning to acknowledge that the web's global nature requires, in some cases, nothing short of a global order. ${ }^{121}$ Sookman's argument is persuasive, and to their credit (and the credit of other pro-property advocates), the intervener concedes that takedown orders engage search engine speech interests along with those of other intermediaries. But in lauding the Court's holding in Equustek, Sookman and other pro-property groups support a test for takedown orders that accords no value to the speech at issue. The primary consideration on this view of the problem is not whether takedown

118. Barry Sookman, "Google v Equustek: Worldwide De-Indexing Order Against Google Upheld by Supreme Court" (28 June 2017), online (blog): Copyright, Intellectual Property, Computer, Internet, e-Commerce Law <www.barrysookman.com/2017/06/28/ worldwide-de-indexing-order-against-google-upheld-by-supreme-court-of-canada> [perma. cc/GYA7-MWMV]. See also Neil Turkewitz, "The Internet as a Less Lawless Place: The Rejection of Form Over Substance" (8 March 2018), online (blog): Medium <medium. com/@nturkewitz_56674/the-internet-as-a-less-lawless-place-the-rejection-of-form-oversubstance-33cf5291ec26> [perma.cc/8HA3-UNFB].

119. DMCA, supra note 66.

120. Cf Ankita Gupta, "Google v Equustek: An Attempt to Domestically Govern a Global Resource" (16 October 2017), online (blog): The Court.ca <www.thecourt.ca/ google-v-equustek-an-attempt-to-domestically-govern-a-global-resource> [perma. cc/2V6G-E7RA]. Gupta argues that the alternative chosen in Equustek of placing the burden on third parties such as Google to prove the contrary-that the order would be unlawful in one or more foreign jurisdiction-will ultimately "stifle innovation and discourage economic competition."

121. Sookman, supra note 118. Cf Ariel Katz, "Google v Equustek: Unnecessarily Hard Cases Make Unnecessarily Bad Law” (30 June 2017), online (blog): University of Toronto Faculty of Law <www.law.utoronto.ca/blog/faculty?focus_area=All\&research=All\&uid=akatz> [perma. cc/QHA8-MLRJ]. Katz suggests that the real issue in this case was not whether a global order was necessary, but whether the underlying property claim had been established:

One of the remarkable things about this case is how little we know about the underlying IP claims. Nowhere in the decision does the Court mention any Canadian IP statute, any specific provision of any such statute, or, in the case of common law claims, refer to the relevant doctrines using their standard legal terminology. The majority opinion says almost nothing. 
orders run a risk of censoring legitimate speech or triggering a chill, but whether they unduly inconvenience the subject of the orders.

On the opposing side, critics of the decision were mainly concerned with what happens when global takedown orders become pervasive. The Electronic Frontier Foundation (EFF) might be accused of overstatement in asserting that Equustek is a "dangerous precedent" that will "expand the power of any court in the world to edit the entire Internet, whether or not the targeted material or site is lawful in another country." ${ }^{122}$ But many observers agreed. ${ }^{123}$ For this group, Justice Fenlon's assertion that "most countries will likely recognize intellectual property rights and view the selling of pirated products as a legal wrong" was beside the point. ${ }^{124}$ The issue is not whether a court or government in one country has the authority to make orders over cyberspace on the basis of a universal moral truth. It is who decides what constitutes such a truth. The precedent that Equustek sets is that a court or government can now censor any online speech it believes to be contrary to a truth it deems universal.

The majority in Equustek declined to engage with this prospect or with the possibility that the order at issue in the case would contribute to a chill of online speech. Yet, as Daphne Keller has argued, a takedown order on speech can readily give rise to chilling effects of a broad potential scope that are subtle, but significant:

A critic of, say, the Vietnamese government may be safely ensconced in the US or Germany, far from the reach of Vietnamese state power. But her online speech is not. It depends on the support of global intermediaries like Google if it is to easily

122. Aaron Mackey, Corynne McSherry, \& Vera Ranieri, “Top Canadian Court Permits Worldwide Internet Censorship" (28 June 2017), online (blog): Electronic Frontier Foundation <www.eff.org/deeplinks/2017/06/top-canadian-court-permits-worldwideinternet-censorship $>$ [perma.cc/7SJ6-9UEP].

123. See e.g. Michael Geist, "Global Internet Takedown Orders Come to Canada: Supreme Court Upholds International Removal of Google Search Results” (28 June 2017), online (blog): Michael Geist, <www.michaelgeist.ca/2017/06/global-internet-takedown-orderscome-canada-supreme-court-upholds-international-removal-google-search-results> [perma. cc/96QU-MKLB]; Daphne Keller, "Ominous: Canadian Court Orders Google to Remove Search Results Globally” (28 June 2017), online (blog): The Center for Internet and Society at Stanford Law School <cyberlaw.stanford.edu/blog/2017/06/ominous-canadian-courtorders-google-remove-search-results-globally> [perma.cc/UC6P-YMZZ]; Mike Masnick, "Canadian Supreme Court Says It's Fine To Censor The Global Internet; Authoritarians \& Hollywood Cheer...” (28 June 2017), online (blog): techdirt <www.techdirt.com/ articles/20170628/11273937689/canadian-supreme-court-says-fine-to-censor-globalinternet-authoritarians-hollywood-cheer.shtml> [perma.cc/LBU8-FND3]; Gupta, supra note 120.

124. Equustek, supra note 1 at para 44. 
be found. In practice it often depends on the support of web hosts like Amazon Web Services, as well. A country with no jurisdictional hooks to the speaker may very well have legal and practical power over these intermediaries. The Canadian decision increases the odds that this power will be exercised on a global rather than national basis-effectively reaching out and silencing speakers on the other side of the world. ${ }^{125}$

The chilling effect that Keller outlines here points to a well-known doctrine in Anglo-American jurisprudence on free expression grounded in the concern that a state sanctioned limitation on speech could hinder truthful reporting or communication by promoting self-censorship. ${ }^{126}$ The doctrine recognizes that potentially affected actors may be less inclined to communicate freely out of a fear of being held liable despite their innocence; reluctant to incur great expense to defend themselves, even if they are eventually vindicated; or dissuaded to speak due to their uncertainty as to the validity of their legal position. ${ }^{127}$ Keller's concerns-echoing those of Google-about the possible impact of Equustek orders becoming a common practice are well supported by a sizable body of scholarship on chilling effects of analogous, though more limited, powers in domestic legislation, such as the notice and takedown regime of the DMCA. ${ }^{128}$ Some of this research supports the concern that, as with the DMCA, global

125. Keller, supra note 123.

126. See Frederick Schauer, "Fear, Risk and the First Amendment: Unraveling the 'Chilling Effect" (1978) 58 BUL Rev 685, tracing the use of the term to Dombrowski v Pfister, 380 US 479 (1965). For an examination of the doctrine in the context of online intermediaries, see Wendy Seltzer, "Free Speech Unmoored in Copyright's Safe Harbor: Chilling Effects of the DMCA on the First Amendment" (2010) 24 Harvard JL \& Tech 171.

127. Seltzer, supra note 126 at 193, drawing on Schauer, supra note 126 at 689.

128. DMCA, supra note 66. Scholarship on chilling effects in the digital sphere, in addition to Seltzer, ibid, includes Jennifer M Urban \& Laura Quilter, "Efficient Process or 'Chilling Effects'? Takedown Notices Under Section 512 of the Digital Millennium Copyright Act" (2005) 22 Santa Clara Computer \& High Tech LJ 621; Judith Townend, "Online chilling effects in England and Wales," online: (2014) 3 Internet Policy Rev 1, <policyreview.info/ articles/analysis/online-chilling-effects-england-and-wales> [perma.cc/4DB4-VTD2]; Jonathon W Penney, "Chilling Effects: Online Surveillance and Wikipedia Use" (2016) 31 BTLJ 117; Zoe Carpou, "Robots, Pirates, and the Rise of the Automated Takedown Regime: Using the DMCA to Fight Piracy and Protect End-Users" (2016) 39 Colum JL \& Arts 551; Jonathon Penney, "Internet Surveillance, Regulation, and Chilling Effects Online: A Comparative Case Study," online: (2017) 6 Internet Policy Rev 1 <policyreview.info/ articles/analysis/internet-surveillance-regulation-and-chilling-effects-online-comparativecase> [perma.cc/2YQT-ZXB2]. I would like to thank an anonymous reviewer of this paper for pointing me to these sources. 
takedown orders could cast a chill on a wider range of speakers (such as artists, activists, and entrepreneurs), as well as large intermediaries. ${ }^{129}$

We might soon, therefore, see a splintering of the internet into differing regimes of access and content, depending on how or where we go online. ${ }^{130}$ We might also see an increasing "sanitization" of the internet as interventions by countries with differing ideas of acceptability become more common. ${ }^{131}$ Katherine Maher, a director of the Wikimedia Foundation, noted that:

If any country can demand the worldwide removal of search results, vast sections of history, science and culture could disappear from the global Internet. This could infringe on our ability to learn about the history of Tiananmen Square, the potential medical properties of cannabis, the discoveries of Darwin, or unsavoury allegations against the U.S. president-elect. ${ }^{132}$

Moreover, as the EFF argues, wealth could complicate matters further "as well-resourced individuals engage in international forum-shopping to impose the one country's restrictive laws regarding free expression on the rest of the world."133

The Supreme Court in Equustek may also have overlooked the implications of the order on the rule of law. Michael Geist noted that if Equustek-type orders become frequent, Google, Twitter, and other intermediaries will often be placed in a position of having to "pick and choose among orders they are willing to follow." ${ }^{34}$ Should they decline to follow overbroad orders from repressive regimes (e.g., Iran and North Korea) and follow only those consistent with the First Amendment? ${ }^{235}$ If so, on what basis? Whereas the Equustek order was imposed to address concerns about lawlessness online, it could readily have the effect of inviting many conflicting orders that would ultimately diminish the rule of law

129. See e.g. Seltzer, supra note 126 at 210-18; Carpou, supra note 128 at 565-67.

130. Davey Alba, “The World May Be Headed For a Fragmented 'Splinternet”" (7 July 2017), online (blog): WIRED <www.wired.com/story/splinternet-global-court-rulings-googlefacebook> [perma.cc/5C9C-Z734].

131. Ibid.

132. Katherine Maher, "When search engines omit results, our rights are jeopardized" The Globe and Mail (9 December 2016) online: <www.theglobeandmail.com/opinion/ when-search-engines-omit-results-our-rights-are-jeopardized/article33240768> [perma.cc/5425-QAB4].

133. Mackey, supra note 122. Cf Paul Ohm, "We Couldn't Kill the Internet if We Tried" (2016) 130 Harv L Rev F 79. Ohm suggests that well-founded concerns about the detrimental impact of judicial or regulatory interventions in cyberspace have been common since the earlier 90s, but are consistently proven overstated as the internet, and software in particular, continues to grow and show itself to be more robust than feared.

134. Geist, supra note 123.

135. Ibid. 
online. ${ }^{136}$ National courts and governments would address rule of law concerns more effectively by acting with greater restraint to avoid creating a mesh of conflicting law. ${ }^{137}$

Both perspectives on Equustek raise valid concerns. But they entail a shift of focus away from a core issue in the case: Why are search links to harmful content a valuable form of speech that merit protection, or at least some weight in the balancing test for granting a takedown order? Critics of Equustek were not unanimous in the view that content takedown orders are never permissible. Most of the debate is focused instead on the general effects of such orders and the best forum for crafting takedown regulations. Yet, the core substantive issue remains: What is the value of speech that may be subject to such orders? Part II considers the Supreme Court's earlier engagement with the nature of links as a basis for the answer to this question, with a view to crafting a more equitable test for takedown orders.

\section{A BETTER BALANCE}

\section{A. CROOKES V NEWTON AND THE COURT'S OTHER THEORY OF LINKS}

As noted earlier, neither the majority nor the dissent in Google $v$ Equustek explored in any depth the issue of search engine links as a form of speech or what protection they warrant. By contrast, the Court in Crookes v Newton ${ }^{138}$ examined hyperlinks as a form of speech in the context of defamation at some length. Despite the fact that Justice Abella wrote the majority opinion in both cases, the thrust of the earlier holding appears to run contrary to the gist of the later holding. On closer inspection, as will be seen below, the cases can be reconciled in part. But more importantly, Crookes offered a theory of links as a form of expression that was grounded in a broader view of the internet as an information medium. ${ }^{139}$ This part will argue that the Court ought to have applied this theory in Equustek. It offers a basis for a more equitable test for takedown orders.

136. Ibid.

137. Ibid. See also Keller, supra note 123.

138. Crookes, supra note 18.

139. This is not to say that it entailed a more expansive concept of free speech. See e.g. Mitchell Drucker, "Canadian v. American Defamation Law: What Can We Learn From Hyperlinks?" (2013) 38 Can-USLJ 141. Drucker notes important differences in the Supreme Court's approach to links in Crookes from that of US appellate courts, applying a more expansive concept of free speech under the First Amendment. 
Crookes $v$ Newton was concerned with whether links to defamatory content constitute a form of publication (thus, in a broader sense, facilitation). ${ }^{140}$ Crookes, a member of the Green Party, had sued several parties for posting allegedly defamatory articles about him online, as part of a "smear campaign" against him and the party. ${ }^{141}$ Newton ran a website in British Columbia on which he posted commentary on the topic of free speech online. One post was titled "Free Speech in Canada," containing two links to defamatory material about Crookes. One link pointed to an article containing defamatory statements, the other to a page containing further links to pages containing defamatory content. Crookes asked Newton to remove the links, but Newton declined. Crookes did not allege that any of the content on Newton's site was defamatory, only that his links constituted publication. ${ }^{142}$ Newton's page had been "viewed" 1,788 times, but no evidence was adduced at trial that any visitors had clicked the links. ${ }^{143}$

The trial judge declined to accept that the presence of a link on a visited page should give rise to a presumption that the impugned content had been accessed. ${ }^{144}$ The court held that links are analogous to footnotes because they refer to, rather than repeat, the content at issue. ${ }^{145}$ Without repetition, there could be no publication. And without evidence that the links had been visited, publication had not been established. At the Court of Appeal, Justices Saunders and Bauman agreed with the footnote analogy and held that links are not a form publication because they do not repeat the content at issue. ${ }^{146}$ The context or language surrounding links may constitute "encouragement or invitation," but this was not the case here. ${ }^{147}$ Nor could access to the linked content be inferred from the fact of the site having been trafficked. ${ }^{148}$

Writing for a majority of the Supreme Court, Justice Abella held that "a hyperlink, by itself, should never be seen as 'publication' of the content to which it refers." ${ }^{149}$ She drew upon earlier US and Canadian jurisprudence to

140. Crookes, supra note 18 at para 3.

141. Ibid at paras 6-8.

142. Ibid at para 10 .

143. Ibid.

144. Ibid at para 11, summarizing findings in Crookes $v$ Wikimedia Foundation Inc, 2008 BCSC 1424.

145. Crookes, supra note 18 at para 11.

146. Ibid at para 12, summarizing findings in Crookes v Wikimedia Foundation Inc, 2009 BCCA 392.

147. Crookes, supra note 18 at para 12 .

148. Ibid, citing paras 89 and 92 of the decision.

149. Ibid at para 14 . 
support a view of hyperlinks as a form of "reference" akin to a footnote ${ }^{150}$ and the proposition that reference without repetition is not publication. ${ }^{151}$ For Justice Abella, links are distinct from other acts that constitute publication, because "on its own [referencing] does not involve exerting control over the content." 152 Justice Abella noted that "[c]ommunicating something is very different from merely communicating that something exists or where it exists." ${ }^{153}$ Control is also crucial. A person might link to a site that changes its content without the person being aware of it. ${ }^{154}$ On the question of whether a link facilitates access to defamatory content, Justice Abella offered a theory clearly in tension with the view of linking in Equustek:

Although the person selecting the content to which he or she wants to link might facilitate the transfer of information (a traditional hallmark of publication), it is equally clear that when a person follows a link they are leaving one source and moving to another. In my view, then, it is the actual creator or poster of the defamatory words in the secondary material who is publishing the libel when a person follows a hyperlink to that content. The ease with which the referenced content can be accessed does not change the fact that, by hyperlinking, an individual is referring the reader to other content. ${ }^{155}$

She added that the ease with which links render content accessible "does not change the reality that a hyperlink, by itself, is content neutral-it expresses no opinion, nor does it have any control over, the content to which it refers." 156 A person linking is merely pointing, not repeating a defamation. Something more is required to transform a link into publication.

Justice Abella justified this approach in light of the Court's recent jurisprudence on expression. The primary concern in earlier case law on defamation had been protecting an individual's reputation. ${ }^{157}$ But in Hill $v$ Church of Scientology of

150. Ibid at para 30 .

151. Ibid at paras 21-24, citing Klein v Biben, 296 NY 638 (NY Ct App 1946) and MacFadden v Anthony, 117 NYS 2d 520 (Sup Ct 1952). See also Carter v British Columbia Federation of Foster Parents Association, 2005 BCCA 398 at para 12. The court stated that: "reference to an article containing defamatory comment without repetition of the comment itself should not be found to be a republication of such defamatory comment."

152. Ibid at para 26.

153. Ibid.

154. Ibid at para 27.

155. Ibid at para 29, citing Dell Computer Corporation v Union des consommateurs, 2007 SCC 34 at paras 97-102.

156. Ibid at para 30 .

157. Ibid at para 32 . 
Toronto, ${ }^{158}$ the Court recognized that defamation also engages "the public's interest in protecting freedom of expression." 159 Recent cases have emphasized "the importance of achieving a proper balance between protecting an individual's reputation and the foundational role of freedom of expression in the development of democratic institutions and values." 160 The majority in Crookes extended this logic to "the core significance of the role of hyperlinking to the Internet." ${ }^{161}$ The majority stated that:

Hyperlinks have long been understood to be critical to communication because they facilitate access to information. ... [I]f the Internet is an endless expanse of information where 'any person ... can become a pamphleteer' then ' $[\mathrm{h}] \mathrm{yper}-\mathrm{links}$ are the paths among websites, creating the bustling street corners for distribution of those pamphlets and inviting passersby to engage more deeply with the issues raised. ${ }^{162}$

Holding that links are a form of publication would risk "seriously restricting the flow of information and, as a result, freedom of expression. The potential 'chill' in how the internet functions could be devastating." 163

The majority had thus made clear that links are important to the internet's broader role as an information medium-but does this mean that links to defamatory content are worth protecting? The decision offered only an indirect response to this question when Justice Abella asserted, "I am not persuaded that exposing mere hyperlinks to the traditional publication rule ultimately protects reputation." "164 The Court in Grant had held that publication requires that the defendant "conveys a defamatory meaning," which depends in turn on whether the words would "tend[] to lower a person in the estimation of right-thinking members of society." 165 The context in which a link is offered might convey a "defamatory meaning," in which case, the link would be publication. However,

158. See ibid at para 31, summarizing Hill v Church of Scientology of Toronto, [1995] 2 SCR 1130.

159. Crookes, supra note 18 at para 31. At para 32, Justice Abella traces the shift away from a focus on protecting reputation to the development of the "honest belief" element in fair comment, in WIC Radio Ltd v Simpson, 2008 SCC 40 and the defence of "responsible communication on matters of public interest" in Grant v Torstar Corp, 2009 SCC 61 [Grant].

160. Crookes, supra note 18 at para 32, citing Grant, supra note 159 at para 1 and Hill, supra note 158 at para 101.

161. Ibid at para 36.

162. Ibid at para 35, citing Anjali Dalal, "Protecting Hyperlinks and Preserving First Amendment Values on the Internet" (2011) 13 U Pa J Const L 1017 at 1019.

163. Ibid at para 36 .

164. Ibid at para 39.

165. Ibid. 
that kind of case involves more than mere reference. ${ }^{166}$ Lacking this additional element, Justice Abella concluded, the "most effective remedy lies with the person who actually created and controls the content." ${ }^{167}$ Applying this test, Newton's links did not constitute publication. ${ }^{168}$

The majority's implied answer to the question of why a "mere reference" to defamatory content in the form a link warrants protection is twofold. First, this is because a link to defamatory content is a mere assertion of fact that something exists: On its own, it is "content-neutral ... expresses no opinion" and has no control over the content to which it refers. ${ }^{169}$ It may have the effect of facilitating, but it should not be considered active facilitation. Secondly, links to defamatory content warrant protection, because links per se are vital to the function of the net as an information medium. A link might facilitate access to harmful content, but the harm of censoring mere links (and the potential chilling effect) would be greater than the further harm that might be avoided to the plaintiff's reputation by removing the link. Where a reference does not repeat a defamation, the "most effective" remedy lies with the source of the defamation itself.

This entire approach to links, however, rests on the assumption that individual links to defamatory content are likely to be less harmful than the source text of the defamation itself. This is clearly not the case where a link to the source appears on a large portal that generates much more traffic to the source than it might attract on its own or more than a blogger or news agency might send it. The case of a large portal presents a conundrum not considered in Crookes-one where the balancing may indeed favour holding the portal liable for publication, on the basis that this would be the most effective way of preventing harm. Yet,

166. Ibid at para 40 .

167. Ibid at para 41.

168. Ibid at para 44. Chief Justice McLachlin, along with Justice Fish, concurred with the majority's theory of hyperlinks, but differed on when a link might constitute publication. Justice Abella asserted that a link crosses the line from reference to publications when "a defendant uses a reference in a manner that in itself conveys defamatory meaning about the plaintiff." See ibid at para 40. It was also noted that this can occur where a link is situated in a context that "conveys defamatory meaning" or where the defendant has "actually expressed something defamatory" or where he or she "repeats the defamatory content." Chief Justice McLachlin and Fish J, by contrast, would find publication if the text "indicates adoption or endorsement of the content of the hyperlinked text." See ibid at para 48. In dissent, Justice Deshamps rejected the notion that control over defamatory content was necessary for publication. Justice Deschamps held that in some circumstances a link, on its own, could constitute publication, suggesting a broader "totality of the circumstances" test. The Court was unanimous in its holding that Newton's links here did not constitute publication. See ibid paras 105-110.

169. Ibid at para 30 . 
holding a portal liable for publication or facilitation would be inconsistent with the majority's theory in Crookes that links are "content-neutral" and merely refer to the existence and location of other content. The solution would seem to be a test, which recognizes that a large portal like Google can inadvertently play a significant part in facilitating harm and is therefore responsible-though not liable-for publication.

Notably, none of the tests set out in the three opinions in Crookes considers the amount of traffic a link generates in assessing whether it constitutes publication. By contrast, for the majority in Equustek, the traffic that Google's links generate formed the primary basis of the holding that Google plays a large role in facilitating the harm at issue; a global takedown order was the most convenient and likely the most effective form of relief. By placing an emphasis on traffic, however, the majority in Equustek failed to do what it did in Crookes-see the links at issue as part of a larger practice of linking per se, a practice that engages a larger set of values and interests.

While it is clear that a greater amount of traffic can change the equation when assessing the role that links play in facilitating or even causing harm, much of the analysis of the nature of links in Crookes still applies to search engines and other intermediaries. Regardless of how much traffic Google sends to other sites, on its own, its index is nothing more than a form of mere reference. It thus engages a right to free expression. One important dimension of this right is the provision of accurate information. As the press group in Equustek argued, even a search link to a site engaging in piracy might still serve an innocent purpose (e.g., research on Datalink). ${ }^{170}$ This does not mean that free speech should prevail absolutely over concerns about harm that Google's traffic might facilitate. It is simply to suggest that expression interests ought to be given some weight when considering whether to impose a global content takedown order. In Equustek, the majority declined to accord them any at all. ${ }^{171}$

\section{B. A MORE EQUITABLE TEST}

At the Supreme Court, Google and its sympathetic intervenors tried unsuccessfully to persuade the Court to adopt a test for imposing a global takedown order other than the one set out in RJR-MacDonald — one that would accord greater weight

170. Reporters Factum, supra note 72 at para 28.

171. Equustek, supra note 1 at para 48. Justice Abella writes: "[t]his is not an order to remove speech that, on its face, engages freedom of expression values, it is an order to de-index websites that are in violation of several court orders. We have not, to date, accepted that freedom of expression requires the facilitation of the unlawful sale of goods." 
to free expression. Assuming that search links to harmful content do still merit protection on the basis that links per se are a valuable form of speech, this part of the commentary attempts to sketch a more equitable test that courts might adopt for issuing injunctive extra-territorial orders to remove content in cases where a portal facilitates by merely linking. It does so by drawing upon two earlier models.

In 2012, Parliament amended the Copyright Act $(C A)^{172}$ to include provisions that serve an analogous role to ones found in the DMCA in the United States, ${ }^{173}$ limiting the liability of ISP and search engines for copyright infringement. ${ }^{174}$ The new section 41.27(1) of the $C A$, dealing with search engines in particular, contemplates a situation in which a search engine is "found to have infringed copyright by making a reproduction of the work or other subject matter or by communicating that reproduction to the public by telecommunication." 175 In these cases, the provision limits the scope of relief against a search engine to an injunction to remove the content where notice has been received and other conditions have been met. ${ }^{176}$ It thus contemplates something like the balance sketched above-i.e., the search engine be held responsible for "communicating" an unlawful reproduction, but not be held liable.

Section 41.27 offers further guidance by setting out factors a court should consider when deciding whether to grant an injunction. Section 41.27(4.1) asks the court to weigh the "harm likely to be suffered by the copyright owner" without the injunction against the "burden imposed" on the search engine,

172. Copyright Act, RSC 1985, c C-42.

173. DMCA, supra note 66 at 165. I credit Google Factum, supra note 45 for suggesting the 2012 amendments to the Copyright Act as a model on which to draw here.

174. CMA, supra note 6. See also Canada, Legal and Legislative Affairs Division, Parliamentary Information and Research Service, Legislative Summary of Bill C-11: An Act to Amend the Copyright Act, by Dara Lithwick and Maxime-Olivier Thibodeau, Publication No 41-1-C11-E (Ottawa: Library of Parliament, 14 October 2011), online: <web.archive.org/web/20170302115527/http://www.lop.parl.gc.ca/content/lop/ LegislativeSummaries/41/1/c11-e.pdf>.

175. The first part of this passage appears to contemplate the auto-complete or snippet-view functions, but the second part would seem to apply more broadly to links to sources of infringing content.

176. In the case of a search engine, the main condition is that a search engine remove reproductions of copyrighted work that might appear on an index incidental to the operation of the portal (caching, autocomplete, etc.) within 30 days of receiving notice. See Copyright Act, supra note 172, ss 41.27(1)-(3). Judicial consideration of the provision is limited. See e.g. Trader v CarGurus, 2017 ONSC 1841. The court held that CarGurus, a site which primarily hosted car ads that duplicated thousands of pictures posted on Autotrader, is not a search engine for the purposes of section 41.27 of the Copyright Act. 
including the "aggregate effect of the injunction"; "whether implementing the injunction would be technically feasible and effective"; "the availability of less burdensome and comparably effective means of preventing" the infringement; and perhaps most significantly, "whether implementing the injunction would interfere with the use of the informational location tool for non-infringing acts."

Collectively, the factors to be weighed here suggest that Parliament had recognized that search engine links engage free speech interests and that an order against a search engine can have wider effects. The factors also imply a view close to the one in Crookes - that links are valuable per se as core to the function of the internet as a communication medium. More crucially, the Act compels courts to balance the interests of a search engine against those of a copyright holder even where the court has "found [the engine] to have infringed copyright by making a reproduction of the work ... or by communicating that reproduction." 177 In other words, even where the court has found that a search engine does more than merely refer by linking - where, for example, through snippet view, caching, or other means, the engine reproduces a work - the court must still consider the impact of an order on the engine's speech interests. The entire test is premised on the view that, despite such infringements, a search engine serves a larger public interest as an information intermediary and courts should tread carefully when imposing orders that impede this function. If Parliament embraced this reasoning in cases where search engines are found to infringe copyright, the same reasoning should apply more readily to cases where a portal merely refers.

A second source on which courts might draw on in crafting a more equitable test is the Manila Principles on Intermediary Liability (Manila Principles). ${ }^{178}$ The Manila Principles emerged from a conference in 2015 of digital rights and free speech advocates in Manila addressing the regulation of online expression. ${ }^{179}$ The document reflects a clear emphasis on the speech rights of intermediaries and places a high bar for content restriction orders. But it warrants considering as an attempt to address competing concerns of a range of stakeholders.

The Manila Principles hold that: (1) intermediaries should be shielded from liability for third-party content; (2) removal orders should require a court order; and (3) orders should be imposed only where necessary and proportionate. ${ }^{180}$

177. Copyright Act, supra note 172, s 41.27(1).

178. Manila Principles, supra note 19.

179. Giancarlo Frosio, "Welcome to the Manila Intermediary Liability Principles!" (27 March 2015), online (blog): The Center for Internet and Society at Stanford Law School <cyberlaw.stanford.edu/blog/2015/03/welcome-manila-intermediary-liability-principles> [perma.cc/8NWR-3KGC].

180. Manila Principles, supra note 19, Principles 1-2, 4. 
Consistent with the holding in Crookes, the Manila Principles call for intermediary immunity for third-party content "in circumstances where they have not been involved in modifying that content." 181 As with the $C A$ provisions discussed above, the Manila Principles would preclude intermediaries from being held liable for "hosting unlawful third-party content" or being required to "monitor content proactively." 182 A court order imposing content restrictions should be premised on "a determination that the content is unlawful in the jurisdiction." 183 Orders would be necessary and proportionate where they targeted the "specific content at issue," involved "the least restrictive technical means," and were limited by geographic scope where the content itself is shown to be "unlawful in a particular geographic region." 184 The document thus reflects a view that harkens back to Crookes - that links and another content online ought to be interfered with cautiously and only after expression interests are clearly outweighed by other, pressing considerations.

The Manila Principles speak of "content restriction" and "intermediary liability," with the latter referring to damages. The text is silent on search engine links to questionable content but does not appear to preclude a restriction order of this kind. ${ }^{185}$ Nor do the Manila Principles prohibit extra-territorial orders. But the text implies that these are appropriate only where a party seeking the order establishes the unlawful nature of the content at issue in the jurisdictions to which the order would extend. Put differently, before a court issues an extra-territorial order, an applicant must demonstrate entitlement based on an extra-territorial right, rather than the court simply assuming it, as was the case in Google v Equustek. ${ }^{186}$ Extra-territorial orders are thus understood to be the exception rather than the rule. Viewing them as exceptional reflects an assumption that

181. Ibid, Principle 1(b).

182. Ibid, Principle 1(d).

183. Ibid, Principle 2(b)(1).

184. Ibid, Principle 4. See especially 4(d), which states: "If content is restricted because it is unlawful in a particular geographic region, and if the intermediary offers a geographically variegated service, then the geographical scope of the content restriction must be so limited."

185. However, the omission might also imply that an Equustek-type order exceeds the reasonable scope of content restriction against an intermediary.

186. Equustek, supra note 1. Justice Abella proposes that it was impractical to require to the plaintiff to prove the order would not violate comity—-would not be unlawful—in each jurisdiction to which the order would apply. The Manila Principles contemplate something different: a requirement to prove an entitlement to an extra-territorial order based on a right that extends extraterritorially (e.g., a property right under international law). See Manila Principles, supra note 19. 
orders extending to jurisdictions where the content has not been established to be unlawful will have unduly deleterious effects on speech.

A more equitable test for content takedown orders might draw, then, on two key features common to the two tests canvassed above: The need to establish necessity and proportionality. ${ }^{187}$ An extra-territorial or global order to remove a link would be necessary only if a form of direct relief against the defendant or the source of harm at issue would not be comparably effective. The order would be proportionate only if its scope constitutes the least intrusive means of addressing the harm at issue in terms of the content restricted, the duration of the order, and its geographic scope.

If this test were applied in Equustek, would a global order have been imposed? Possibly. But Equustek would have had to establish it was necessary by showing that it had a right extending beyond Canada to enjoin the defendant from selling the products at issue anywhere in the world. The majority of the Supreme Court failed to address this issue and Justices Côté and Rowe in dissent emphasized that such a right had not been established by the litigation to that point. The plaintiff would also have needed to demonstrate proportionality by showing that a removal order against Google would be more effective than an order against the company running the server (or the ISP) hosting the defendant's websites. The courts at all three levels in Equustek failed to give this possibility adequate consideration. In granting the order, Justice Fenlon noted only in passing that Datalink had become a "virtual company" conducting business through a "complex and ever expanding network of websites," without detailing the plaintiff's efforts to locate the particular servers on which the sites were hosted. ${ }^{188}$ The Court of Appeal, which upheld Justice Fenlon's order, was similarly vague on this point, noting that "[a]lthough we are advised that the plaintiffs have made some efforts to determine where the defendants manufacture and warehouse their product, and to determine where the product is shipped from, they have not been successful." 189 The majority of the Supreme Court overlooked the issue entirely.

By contrast, the dissent highlighted the prospect of an order against the relevant server or ISP as a viable alternative. ${ }^{190}$ This possibility had come to light in a later decision of the Court of Appeal (relating to an order for the seizure of assets) indicating that Datalink and associated persons had assets in France and

187. Intervenors in Equustek before the Supreme Court of Canada had also included these factors in their proposed tests. See supra note 73.

188. Equustek Solutions Inc, supra note 14 at para 7.

189. Equustek BCCA, supra note 40 at para 18.

190. Equustek, supra note 1 at para 81. 
that French courts were receptive to an application to seize them. ${ }^{191}$ Noting this information, Justices Côté and Rowe suggested the lower courts should have directed Equustek to try that route first and possibly also to "pursue injunctive relief against the ISPs" hosting Datalink's sites. ${ }^{192}$ A further possibility was that "Equustek could initiate contempt proceedings in France or in any other jurisdiction with a link to the illegal websites." 193 There were at least a few options to consider. Once again, they may have been found impractical or ineffective. However, they ought to have been canvassed at greater length.

\section{CONCLUSION}

Google v Equustek is part of a broader trend among courts and lawmakers to view online intermediaries as facilitators of harm, where they point a critical mass of users to the sources of harmful content. The trend runs contrary to a body of law recognizing a need to protect the freedom to link or refer to content in light of the importance of links to the function of the internet as an information medium. However, the critical mass theory of links as a form of inadvertent facilitation is undeniably valid: In some cases, large portals and search engines do significantly contribute to the harm at issue by generating most of the traffic. In some cases, ordering a search engine or large intermediary to remove links or to block access may indeed be a necessary and proportionate response. Yet, courts cannot make fair assessments of necessity and proportionality here without first recognizing that all links bear value as speech and implicate the interests of both intermediaries and users - even those that point to harmful content.

Critics of the Equustek decision have thus far focused mainly on the potential impact of a decision to impose a global delisting order and the fear that it will encourage courts in illiberal countries to impose similar orders premised on differing views of right and wrong. An equally crucial take away from the decision, from the current wave of case law and regulation premised on the critical mass theory of linking, is that advocates of free speech online need to be clearer about the value of links to harmful content in particular and why they merit protection. Equustek marked Google's repeated failure to make a clear and persuasive case on this point at the Supreme Court. Without explaining how or why, it merely asserted that all of its links, including those to sources of harmful content, were "relevant" to users and to forms of expression that warrant a measure of protection

191. Equustek v Jack, supra note 116 at para 24.

192. Ibid at para 81.

193. Ibid. 
in accordance with common law and Charter jurisprudence. The majority of the Court responded by making a similar unsupported assertion, that a link to a source of piracy bears little if any value as speech.

The reasoning in Crookes offers advocates of free expression a basis for a more persuasive case. Where search engines and large portals point to harmful content, the links may need to be removed. However, courts should be cautious in interfering and in ordering them to do so, given that links and portals per se play a central role in the function of the internet as a public forum. Courts should therefore never apply a test for content removal-much less a global removal order-premised on the view that no valid expression interests are engaged by individual links or forms of reference. The Supreme Court's failure to recognize this was shortsighted and the test it crafted in Equustek should not be followed by other courts. The concerns about its potential impact as a precedent canvassed above are valid. A more equitable test, aiming to accord greater protection of the speech interests of large platforms, would likely go some distance in addressing these concerns, thus limiting the impact of takedown orders on the internet's function as a global public sphere. 